\title{
Clinical Reasoning: Leg weakness and stiffness at the emergency room
}

Karolina af Edholm, MD, Christer Lidman, MD, PhD, Sören Andersson, MD, PhD, Göran Solders, MD, PhD, and Martin Paucar, MD, PhD

Neurology ${ }^{\circledR}$ 2019;92:e622-e625. doi:10.1212/WNL.0000000000006885

\section{Section 1}

A 48-year-old woman from the Maghreb came to the emergency department with insidious gait difficulties, urgency, and constipation starting 6 months prior to the visit. The patient's complaints consisted of weakness, stiffness, and pain in her legs. Her medical history consisted of Hashimoto thyroiditis and breast cancer, with the latter having motivated surgery 4 months prior to admission. Histopathologic examination had demonstrated ductal cancer sensitive to estrogen and mapping with sentinel node biopsy ruled out metastasis. For that reason, the patient was treated with local radiation given weekly over 1 month and treatment with tamoxifen was started. Physical examination upon admission demonstrated weakness and spasticity in both legs. Reflexes were brisk; bilateral nonsustained foot clonus and Babinski sign were also present. Bilateral dorsal flexion was reduced, but vibration and sensation to touch and pinprick were normal. Sphincter tonus was reduced; systemic manifestations such as myalgias, fever, skin rashes, uveitis, sicca, and arthritic joints were absent.

\section{Questions for consideration:}

1. What is the proper workup?

2. What is the differential diagnosis of this presentation?

\section{Correspondence}

Dr. Paucar

martin.paucar-arce@sll.se

\section{MORE ONLINE}

- Video

\section{GO TO SECTION 2}

From the Departments of Neurology (K.a.E., G.S., M.P.), Infectious Diseases (C.L.), and Neurophysiology (G.S.), Karolinska University Hospital, Solna; Department of Clinical Neuroscience (K.a.E., G.S., M.P.), Karolinska Institutet, Stockholm; and Department of Microbiology (S.A.), University Hospital in Örebro, Sweden.

Go to Neurology.org/N for full disclosures. Funding information and disclosures deemed relevant by the authors, if any, are provided at the end of the article. 


\section{Section 2}

The phenomenology is compatible with spastic paraparesis. The history of cancer raises the suspicion of spinal metastasis or paraneoplastic myelopathy. However, at the time point of examination and during follow-up (5 years later) no evidence of cancer recurrence was detected. The patient underwent investigations with laboratory tests, MRI of the brain and spinal cord with gadolinium contrast, neurophysiologic tests, and lumbar puncture. Neuroimaging yielded normal results but motor evoked potential demonstrated affection of the corticospinal tracts likely at the thoracic level. Additional investigations with EMG did not display neurogenic potentials, myokymic discharges, fibrillation potentials, positive sharp waves, or fasciculation potentials, making amyotrophic lateral sclerosis unlikely. However, upper motor neuron signs with a protracted course may indicate primary lateral sclerosis. Nerve conduction velocities displayed bilateral carpal tunnel syndrome, which in this context is a coincidental finding. HIV is also associated with myelopathy but in this case there was no evidence of immunosuppression and testing for this virus was negative. Analysis of the CSF demonstrated monocytic pleocytosis but PCR and serologic analyses for the most common neurotropic viruses and bacteria were negative (table 1). Screening with rheumatologic, GAD, and onconeuronal autoantibodies was also negative. Cobalamin, folic acid levels, and routine laboratory tests were normal. In a patient with a recent history of breast cancer, paraneoplastic myelopathy has to be considered; however, normal imaging, normal protein levels in the CSF, and absence of onconeuronal antibodies argued against it. Common causes of spastic paraparesis (spinal cord compression, multiple sclerosis, transverse myelitis, and vascular malformation) were otherwise ruled out by the normal imaging. Normal imaging makes radiation myelopathy unlikely. As the differential diagnosis for spastic paraparesis is broad, we summarize it in table e-1 (doi.org/10.5061/dryad.f02h5k2).

The patient's condition progressed, resulting in major gait disability; the patient requires the constant use of a walker for mobility and her leg spasticity increased (modified Ashworth score 3) (video). Spastic paraplegia rating scale at age 53 was
Table 1 Laboratory tests at admission

\begin{tabular}{|c|c|}
\hline Measure/metabolite & Value (reference value) \\
\hline Blood: leukocytes & $4.4 \times 10^{9} / L\left(3.5-8.8 \times 10^{9} / L\right)$ \\
\hline Blood: erythrocytes & $3.9 \times 10^{12} / \mathrm{L}\left(3.9-5.2 \times 10^{12} / \mathrm{L}\right)$ \\
\hline Blood: hemoglobin, g/L & $113(117-153)$ \\
\hline Plasma: C-reactive protein, mg/L & $<1(<3)$ \\
\hline Plasma: creatinine, $\mu \mathrm{mol} / \mathrm{L}$ & $56(<90)$ \\
\hline Plasma: calcium, mmol/L & $2.24(2.15-2.50)$ \\
\hline Plasma: albumin, g/L & $36(36-45)$ \\
\hline Plasma: IgG, g/L & $13.0(6.7-14.5)$ \\
\hline CSF: leukocyte particle concentration ${ }^{a}$ & $15 \times 10^{6} / \mathrm{L}\left(0-5 \times 10^{6} / \mathrm{L}\right)$ \\
\hline CSF: polymorphonuclear leukocytes & $0\left(<1 \times 10^{6} / L\right)$ \\
\hline CSF: monocytes ${ }^{a}$ & $15 \times 10^{6} / \mathrm{L}\left(0-5 \times 10^{6} / \mathrm{L}\right)$ \\
\hline CSF: erythrocytes ${ }^{a}$ & $20 \times 10^{6} / L\left(<1 \times 10^{6} / L\right)$ \\
\hline CSF: albumin, mg/L & $228(<320)$ \\
\hline CSF: P-albumin ratio & $6.4 \times 10^{-3} / L(<0.7)$ \\
\hline CSF: IgG, mg/L ${ }^{a}$ & $48(<45)$ \\
\hline CSF: IgG index & $0.58(<0.7)$ \\
\hline Serum: $\beta 2$ microglobulin, $\mathrm{mg} / \mathrm{L}^{\mathrm{a}}$ & $2.7(<2.0)$ \\
\hline
\end{tabular}

Abbreviation: IgG = immunoglobulin G.

White blood cell count differential and immunoglobulin levels were normal. Serology for Lyme disease and syphilis in both serum and CSF was negative. PCR for the following viruses was also negative: cytomegalovirus, enteroviruses, herpes simplex virus type 1 and 2, human herpesvirus 6, and varicella-zoster virus DNA.

a Abnormal value.

39 points (range $0-52$ points), with the patient developing depression during the course of the disease.

\section{Questions for consideration:}

1. Is there any additional analysis to consider?

2. Is there any treatment indicated at this point?

GO TO SECTION 3 


\section{Section 3}

The patient turned out to be seropositive for human T-cell lymphotropic (formerly leukemia) virus (HTLV-1). This serologic finding was confirmed in a reference laboratory. Antibodies against HTLV-1 were found in the CSF as well. Taken together, the patient met the criteria for HTLV-1-associated myelopathy (HAM), previously known as tropical spastic paraparesis (TSP). ${ }^{1}$ HAM/TSP is a feared incurable complication of HTLV-1 infection. Onset is usually at adult age and more common among women. HAM/TSP is characterized by slowly progressive spastic paraparesis, bladder dysfunction, constipation, and sensory symptoms. The association with HTLV-1 was discovered independently in Martinique and in Japan. ${ }^{2,3}$ Neuroimaging usually displays nonspecific white matter abnormalities in the brain and spinal cord but can be normal early in the course of HAM/TSP. Lymphocyte infiltration starts likely at the thoracic level of the spinal cord, leading to its demyelination and atrophy. ${ }^{1}$ For women, sexually acquired HTLV-1 has been proposed as a risk factor for the development of HAM/TSP. ${ }^{4}$ Proviral load (PVL) measures viral genetic material integrated in peripheral blood mononuclear cells with levels over $1 \%$ considered as a proxy biomarker for complications associated with HTLV-1 infection. ${ }^{5}$ HAM/TSP is characterized by higher PVL values compared with asymptomatic carriers. ${ }^{5}$ Increasing PVL has also been reported in other HTLV-1 complications, ${ }^{6}$ though PVL is neither specific nor helpful to predict the kind of complications. In this current case, PVL was $13.2 \%$ at the time of diagnosis.

Other than the Caribbean basin, HTLV-1 foci are found in Southern Japan, the Middle East, sub-Saharan Africa, South America, and among Aborigines in Australia. Based on prevalence data in known endemic regions, it is believed that 5-10 million individuals are infected with HTLV-1 worldwide. ${ }^{7}$

Clinical studies with antiviral drugs have been disappointing in HAM/TSP; hence treatment is largely symptomatic. ${ }^{1,6}$ IV steroids can be used when progression rate is rapid; however, in this case, IV steroids were not beneficial. Methotrexate was also tried, but discontinued due to limited compliance. Botulinum toxin injections were given to both legs but the patient declined continuation. Symptomatic treatment with tolterodine and citalopram was initiated during the course of disease; neither gabapentin nor baclofen provided relief for spasticity and were discontinued; tizanidine was added later on. A recent trial demonstrated that mogamulizumab reduced spasticity, PVL, and markers of inflammation in the CSF in a small cohort of Japanese patients with HAM/TSP. ${ }^{8}$ The long-term benefit and potential complications of this treatment are unknown.

Of note, HTLV-1 does not infect neurons, microglia, or astrocytes, ${ }^{5}$ and a solid body of evidence indicates an exaggerated immunologic reaction that involves mainly astrocytes and lymphocyte infiltration into the spinal cord. The process leading to a chronic myelitis is mediated by CXCL10. ${ }^{9}$
A new cancer disease, adult T-cell leukemia, was characterized in Japan in the 1970s. Later, Robert Gallo's ${ }^{10}$ group isolated HTLV-1 in tissue samples from these patients, thereby proving for the first time that a virus was associated with human cancer diseases. Some HTLV-1-positive patients are prone to severe immunosuppression and face recurrent or disseminated infection with Strongyloides stercolaris, but this current case was seronegative for this parasite. Acute myelitis caused by HTLV-1 is rare; other neurologic manifestations than spastic paraparesis are also rare and include cerebellar ataxia and cranial nerve affection. Other conditions associated with HTLV-1 include uveitis, polymyositis, and infective dermatitis. $^{6}$

HAM/TSP and other complications secondary to HTLV-1 infection constitute neglected conditions. The pressing need for better disease control, biomarkers, vaccines, and treatments has been highlighted recently by leading experts in the field. $^{11}$

There are several teaching points in this case. First, it is an unusual etiology that requires a high index of suspicion. Travel to and migration from endemic regions elevates the probability of meeting HTLV-1-positive patients in countries with low prevalence. Thus, HTLV-1 should be considered in the context of myelopathies of unknown cause. Second, even though treatment is symptomatic and the prognosis dire, correct diagnosis is important in order to prevent further transmission.

\section{Author contributions}

M. Paucar, K. af Edholm, C. Lidman, and S. Andersson: study concept and data collection. M. Paucar wrote the first draft. G. Solders, S. Andersson, and C. Lidman: editing of the manuscript.

\section{Acknowledgment}

The authors thank the patient for participation, Kerstin Malm for assistance with the confirmatory test for HTLV-1, and Drs. Rayomand Press and Jan Weinberg for advice.

\section{Study funding}

Stockholm County Council.

\section{Disclosure}

The authors report no disclosures relevant to the manuscript. Go to Neurology.org/N for full disclosures.

\section{References}

1. De Castro-Costa CM, Araújo AQ, Barreto MM, et al. Proposal for diagnostic criteria of tropical spastic paraparesis/HTLV-I-associated myelopathy (TSP/HAM). AIDS Res Hum Retroviruses 2006;22:931-935.

2. Gessain A, Barin F, Vernant JC, et al. Antibodies to human T-lymphotropic virus type $I$ in patients with tropical spastic paraparesis. Lancet 1985;2: 407-410.

3. Osame M, Usuku K, Izumo S, et al. HTLV-I associated myelopathy: a new clinical entity. Lancet 1986;1:1031-1032.

4. Maloney EM, Cleghorn FR, Morgan OS, et al. Incidence of HTLV-I-associated myelopathy/tropical spastic paraparesis (HAM/TSP) in Jamaica and Trinidad. J Acquir Immune Defic Syndr Hum Retrovirol 1998;17:167-170. 
5. Nagai M, Usuku K, Matsumoto W, et al. Analysis of HTLV-I proviral load in 202 HAM/TSP patients and 243 asymptomatic HTLV-I carriers: high proviral load strongly predisposes to HAM/TSP. J Neurovirol 1998;4:586-593.

6. Gonçalves DU, Proietti FA, Ribas JG, et al. Epidemiology, treatment, and prevention of human T-cell leukemia virus type 1-associated diseases. Clin Microbiol Rev 2010; 23:577-589.

7. Gessain A, Cassar O. Epidemiological aspects and world distribution of HTLV-1 infection. Front Microbiol 2012;3:388.
8. Sato T, Coler-Reilly ALG, Yagishita N, et al. Mogamulizumab (Anti-CCR4) in HTLV-1-associated myelopathy. N Engl J Med 2018;378:529-538.

9. Ando H, Sato T, Tomaru U, et al. Positive feedback loop via astrocytes causes chronic inflammation in virus-associated myelopathy. Brain 2013;136:2876-2887.

10. Gallo RC. The discovery of the first human retrovirus: HTLV-1 and HTLV-2. Retrovirology 2005;2:17.

11. Martin F, Tagaya Y, Gallo R. Time to eradicate HTLV-1: an open letter to WHO. Lancet 2018;391:1893-1894. 


\section{Neurology}

\section{Clinical Reasoning: Leg weakness and stiffness at the emergency room}

Karolina af Edholm, Christer Lidman, Sören Andersson, et al.

Neurology 2019;92;e622-e625

DOI 10.1212/WNL.0000000000006885

This information is current as of February 4, 2019

\section{Updated Information \&} Services

References

Subspecialty Collections

Permissions \& Licensing

Reprints including high resolution figures, can be found at: http://n.neurology.org/content/92/6/e622.full

This article cites 11 articles, 1 of which you can access for free at: http://n.neurology.org/content/92/6/e622.full\#ref-list-1

This article, along with others on similar topics, appears in the following collection(s):

All Spinal Cord

http://n.neurology.org/cgi/collection/all_spinal_cord Spastic paraplegia

http://n.neurology.org/cgi/collection/spastic_paraplegia

Information about reproducing this article in parts (figures,tables) or in its entirety can be found online at:

http://www.neurology.org/about/about_the_journal\#permissions

Information about ordering reprints can be found online:

http://n.neurology.org/subscribers/advertise

Neurology ${ }^{\circledR}$ is the official journal of the American Academy of Neurology. Published continuously since 1951, it is now a weekly with 48 issues per year. Copyright @ 2019 American Academy of Neurology. All rights reserved. Print ISSN: 0028-3878. Online ISSN: 1526-632X.

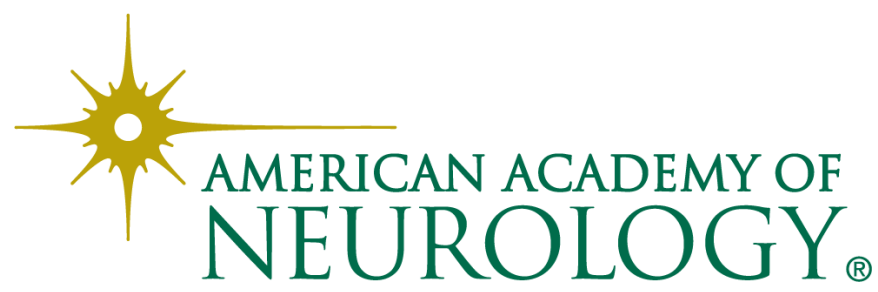

